\title{
SOCIAL MANDATE FOR POLISH LEGISLATIVE AND EXECUTIVE POWER CENTRAL ORGANS IN THE FACE OF CHALLENGES THAT AWAIT THE EU. THE QUESTION OF FOR PUBLIC PARTICIPATION
}

\begin{abstract}
Due to amalgamation of Polish and EU systems, the shape of many public policies in the country is the consequence of decisions taken within the EU - but what is more important - with participation of Poles. Complexity of the challenges ahead demands making decisions that the society shall feel are acceptable, or even proceeded with their co-authorship. Relevantly high degree of cooperation, co-decision making and shared responsibility - between executive and legislative power and non-public entities, within political decision making, is important in order to get as properly stable as possible standpoint of Poland, and for efficient implementation. Because of that, the aim of this analysis is the search for the answer to the question whether within challenges that await the EU, we may find those, that will lay especially in the field of interest of Polish non-public entities. In addition - is it justified (and to what extend) to include in such cases those entities into processes of working out standpoints of Polish officials. With such a research objective a thesis is being advanced, that in Poland awareness of EU functioning mechanisms, but also the level of inclusion of non-public entities into political decision making, is little and in face of challenges awaiting the union it is necessary to raise it.
\end{abstract}

* Faculty of Political Sciences and International Studies, Nicolaus Copernicus University in Toruń, Poland, e-mail: radekpotorski@wp.pl 


\section{Key words}

public participation, political decision making, Brexit, 'Islamic State', the rule of law in Poland, European Union

\section{Introduction}

Today, even if we take just a general look at the situation in Europe, but also outside its borders, it is hard to deny that the European Union stands in front of significant challenges. Some of them might lead to important changes within the treaties or to introduction of legal acts, which will have a serious echo within member states' political systems. Such thesis seems legitimate if we just take a brief look at internal situation within the European Union, but also at the international politics arena. The character of many cases proves that changes within relations of member states and the EU are needed. On the one hand, introduction of significant modifications to a state membership paradigm in the integration structure, which is the Union, will demand acceptance, even if not formal, from the sovereign. In the other case, member-states public authorities, that accept such serious changes, will lose trust and political support of their voters. On the other hand, it seems that nature and scale of challenges that await EU member states causes that a general approach to solving them, taking into account the greatest amount of data, experts knowledge or even various standpoints in regard to various issues, will be necessary. Of course part of them is outside the structures of public authorities, therefore in order to gain high level of arrangements made to respond to challenges awaiting the EU, it is necessary to treat subjects located outside public structures as some sort of a resource, or even a partner in creating standpoints of certain states during the whole process of challenging next difficulties.

The aim of this analysis is to bring special attention, within pictured above mechanism, to case of Poland, and especially to the question whether within challenges that await the EU we may find those that will lay especially in the field of interest of Polish non-public entities. In addition - is it justified (and to what extent) to include in such cases those entities into processes of working out the standpoints of Polish officials. With such a research objective a thesis is being advanced that in Poland awareness of EU functioning mechanisms, but also the level of inclusion non-public entities into political decision making, is little and in face of challenges awaiting the union it is necessary to raise it. 
The substantive scope of the research field shall be located within the situation, which refers to, or of which solution, according to suggested prognosis, will have to be based on modification of significant provisions (essentialia negotii) - agreements which constitute EU primary law. In order to be precise here - it is about matters which shall be included into EU political system, of which change, or activation influences the position of Poland within the union.

The subjective scope of the research refers to two main types of subjects in regard to public law, which are present in Poland (public and non-public entities). Non-public entities are here physical persons and all legal entities, who are not qualified into the meaning of the term public entities. Second ones are state treasury and all entities directly included into state structures, meaning qualified to public finance sector, according to the art. 9, Act of $27^{\text {th }}$ of August 2009 on Public Finances (Act 1240/2009), and also all entities performing public tasks as in art. 3, Act of $29^{\text {th }}$ of January 2004 on Public Procurememnt (Act 177/2004) ${ }^{1}$. However, when it comes to public entities, in order to perform this analysis, only central organs of legislative or executive power has been taken into account ${ }^{2}$. Focus on that certain entities is justified by the fact that on the one hand all of them are relaying on electoral outcomes (directly: Sejm, Senate, the President, or indirectly: Council of Ministers), and on the other these are the entities which play a crucial role within EU policy-making processes ${ }^{3}$.

The time scope of the research field refers to the so-called 'current situation' of the EU political system functioning. Therefore these are matters that still have not met their final solution, are now observed (even if their sources are rooted in a distant past), or their occurrence shall be assumed with high probability.

1 On transfer of public tasks to private law entities see: Biernat, 1994.

2 I mean here, according to art. 10 of Polish Constitution: Sejm, Senate (both legislative power organs), as well as the President and the Council of Ministers (executive power organs).

3 Members of the Council of Ministers and the President (who might, but does not have to do) are directly members of EU decision-making institutions (in relevant configuration - in the Council of the European Union and European Council, or - in case of the President - in European Council). The parliament is responsible for proper implementation of the EU law, and its consent is necessary to introduce changes within EU treaties. 


\section{Political decision making in Poland and public participation as its part}

Due to amalgamation of Polish and EU systems, the shape of many public policies in the country is the consequence of decisions taken within the EU but what is more important - with participation of Poles. Complexity of the challenges ahead demands making decisions that the society shall feel are acceptable, or even proceeded with their co-authorship. Relevantly high degree of cooperation, co-decision making and shared responsibility - between executive and legislative power and non-public entities, within political decision making, is important in order to get as properly stable as possible standpoint of Poland, and for efficient implementation.

Taking a step forward - one may assume that for efficient functioning of Poland within the EU decision-making system, respectively intense and multiaspect relation is necessary, meaning cooperation in regard to public issues between those who received the mandate to perform public offices (govern) and those who delegated that power. This relationship is defined as public participation (Olech \& Kaźmierczak, 2011, p. 101-102).

It shall be emphasized that public participation may take various forms, if we take into account the initiator, but also matters of voluntary entrance into that relationship of interdependence. That is why four categories of such participation are recognized. The first one is obligatory participation, which is activity of citizens mandatory in the law, because it is supportive to public authorities, necessary to perform their statutory functions and tasks (i.e.: obligation to pay taxes) ${ }^{4}$. The second type is electoral participation, which includes activity necessary to nominate candidates of the society and to select among them representatives, who will perform decision-making functions within various levels of government ${ }^{5}$. The third type is public activity, which consists of actions initiated by citizens and controlled by them in order to influence decisions made by public representatives or voters (e.g.: protest, ombudsman or lobbying, by which I mean here delivery of information in order to convince authorities to someone's arguments). The fourth type is engagement of citizens, which includes actions initiated and controlled by public authorities while performing their statutory administrative or managerial tasks. The basic aim of such actions is to improve

4 Another example of obligatory participation is taking part in jury during a trial a key institution in the American system.

5 That includes, e.g. referenda, if are legally obligatory. 
the decision-making process as well as quality of performed public tasks, so to ensure possible consensus and support from the citizens (see: Kaźmierczak, 2011, p. 83-99; Olech \& Kaźmierczak, 2011, p. 101-102). What is more, in various ways the level of non-public engagement in taking public decisions might vary. According to a clear tendency in the literature, three possible situations are distinguished, i.e.: informing, consulting and co-decision making ${ }^{6}$.

If we bring that patterns to Polish public life, one shall first emphasize results from public survey research - that non-public entities strongly state that - in their opinion - they do not have any influence on directions of public policies. In 201470 percent of respondents claimed that people just like themselves have little influence in shaping state public policies ${ }^{7}$. In regard to local arena -47 percent respondents claimed that in that matter their opinions are not important ${ }^{8}$. It might partially be a result of the fact - as experts see it - that in Poland the most engaging forms of inclusion of non-public entities are being used, meaning - information or basic forms of consultations. On the other hand, important feature of that political system is a lack of vivid social activism, directed at cooperation with public authorities, which is in turn mostly caused by historical background. One may state that Polish society had for many years functioned aside or in contrary to public authorities, and that is why it simply does not have a habit of such cooperation. At the same time authorities are being accused of intentional action against its citizens.

Apart from that it is hard to deny that the speed of political changes during the last three decades did not let participants of the political system to fully, in regard to public policy making, adjust to the changing reality ${ }^{9}$. That is why

6 Each of the types divides into further levels put in order according to actual inclusion of non-public entities into decision-making processes, creating in this way the so-called ladder of participation. (Długosz, Wygański, \& Tański, 2005, p. 26, 35; Krzyżanowska \& Faciejew, 2009, p. 15). Similar division is suggested also by Gramberger or Elliott et. al. (see: Gramberger, 2001, p. 16; Elliott, Heesterbeek, Lukensmyer \& Slocum, 2003, p. 9).

7 Some improvement has been noted between 2007 and 2012, when number of people, who claimed to have influence on public life in Poland, amounted from about one fourth to more than one third. In 2013 significant drop of that group is observed - probably because of a large rise of disappointment with the current politics (CBOS, 2014a, p. 3).

8 Fact of influence on their municipality or town has been confirmed by 51 percent of respondents (CBOS, 2014a, p. 4).

9 Relatively fast after shift from an authoritarian system in Poland and its public policy-making procedures to a democratic system and anew created relations between authorities and non-public entities, Poland entered the EU structures - an incredibly complex political system, which again has influenced change of decision-making mechanisms. 
many Polish actors of public life still did not work out such habits, as well as knowledge on benefits resulting from participation in public policy making. At the same time, among non-public entities, a sense of isolation rises in relation to bodies that make decisions. It is obvious that in such a situation it is hard to take a political decision, which would be both adequate to circumstances and that would gain understanding and favor from non-public entities.

The situation is ineffective. An analysis of relations between public and nonpublic entities within shaping public policies lets us notice certain mutual benefits. Non-public entities, by gaining, which is in their interest, larger influence on decision making, become stronger promoters or defenders of certain decisions. On the other hand, public authorities get, in turn for sharing their 'empire', while working on a decision, a new ground to attain special information, dialog with the involved, and sometimes even persuasion. After some solution is adopted the event gets strong legitimacy and co-sharing of responsibility as a consequence. It shall be reminded that the more inclusion of the non-public is real, the greater is co-responsibility of others for adoption of a certain solution ${ }^{10}$.

Having in mind the current situation, it seems that in Poland participants of observable mechanisms of public decision making are not fully using the potential of such interdependence. It is fascinating, if we consider the fact that a growing level of public participation may positively influence both quality and social legitimacy within creation of EU public policies.

Of course one may ask a question - does the EU stand in front of challenges, of which solution will demand wide participation of non-public entities, or are these matters that belong rather to the category of ordinary issues. Those include situations when governments have electoral mandate strong enough to take action, and also such when within their own resources they have enough skills and knowledge to play that role the most effectively. Finding answers to these questions is the goal of the next step of the analysis.

${ }_{10}$ Within quoted earlier ladder of participation that would be its last levels, which refer to co-decision making. One of these is to make non-public entities an equal partner in taking political decisions, meaning a situation when before taking a political decision public entities cooperate with social partners (i.e.: as negotiations or joint planning) and together take a compromise, joint political decision, i.e.: in a form of a agreement or common program. The last level within the ladder of participation, the level of co-decision making, is transfer made by political bodies to groups or social partners and acceptance of such decisions, with potential control of its procedural legality and compliance of such decisions with the current legal system - i.e.: referenda, collective bargaining agreements (see: Długosz, Wygański \& Tański, op.cit., p. 26, 35). 


\section{Fundamental challenges ahead of the EU. An attempt to diagnose from the perspective of Polish interests}

Events during the last months, despite being unexpected, bring a challenge that is hard to ignore, and the outcome of which will definitely enforce the EU to reform. One may state that for the whole institution this case is now challenge number one. Since June 2016 British exit is widely discussed. According to the art. 50 of Treaty of the European Union, a state has to submit an application (notification) and since that date interested parties have two years to agree on conditions of the contract that is the basis to bring the intention into life. However, which is being underlined by many experts, the treaty has some imprecise provisions (see i.e.: Barcz, 2016; Reid, 2016). It seems that it will need some explanation in two aspects.

First of all, these are procedural matters that refer to the very process of making contracts on leaving the EU. It may turn out to be necessary to determine what precisely that sentence means: 'the Union shall negotiate and conclude an agreement with that State, setting out the arrangements for its withdrawal, taking account of the framework for its future relationship with the Union' (TEU, art. 50, para 2.). Definitely it cannot mean an arrangement referring to all aspects of coming out. First of all, the statement that Union is the party (not Union and member states) determines what shall be taken into account within the objective aspect. The EU can make arrangements only within its exclusive competences (TEU, art. 3). In other aspects detailed agreements have to be made with member states (or with member states and the Union $\left.{ }^{11}\right)^{12}$. Another type of matters, which should be qualified to the wide category of procedural matters,

11 It shall be mentioned that of course leaving the EU will enforce negotiation of new agreements with United Kingdom and third parties, of which relations with the UK have been so far regulated within EU relations.

12 Another type of a similar problem, that will have to be solved, is the issue of clarifying procedures of taking decisions by the EU during negotiations with the UK. It may refer to i.e. voting technique of Council of the European Union during the whole process. In art. 50 para. 2 of the TEU we read about a qualified majority in regard to that matter, but we also have art. 207 para. 4 of the Treaty on the Functioning of the European Union, that is on making agreements by the EU on common trade policy, in which unanimity is demanded (it is hard to assume, that Brexit agreement does not refer to that). One shall raise a question then - is it a lex specialis provision regarding art. 50 of TEU? If yes, one must introduce procedure of unanimity, of course excluding the exiting state (see also: Barcz, op.cit., p. 8). 
and which might demand an explanation, are all cases referring to the UK legal status from the beginning till the end of the process and after it is finished. It should be especially explained what legal status the UK will have once agreement on framework of the exit is made until each detailed agreement comes into force (if a whole bundle is not adopted on one time - main agreement and additional ones). Additionally, already now another problem has been indicated - what will be the status of officials representing the UK (including EU parliament MPs, who are nowhere mentioned in art. 50 of TEU ${ }^{13}$, who would take part in passing new law, which would come into force already after two years since the notification? Finally, one shall not forget questions regarding status of Scotland, if the country would choose to stay in the EU (and how potentially it should procedurally be like). Regulating that issues is crucial to actually make this procedure clear.

The second kind of issues, that will demand clarification, are substantive matters related to Brexit. One shall remember that the treaty sends us only to the agreement, which should contain all detailed solutions of legal relations between parties concerned. The agreement must be worked out through negotiations. On the one hand, United Kingdom, as we should assume, will strive for keeping as many as possible beneficial economic elements. These are mostly: freedom of services (i.e. financial) provided on the British territory, or free access of their goods to the EU market. On the other hand, UK will try to limit duties that are imposed due to the membership. Of course, it refers to issues of great concern of Poland. United Kingdom is a net contributor. It means that it is one of the countries that pay more than they get from the EU budget. Greatest part of EU finances is now spent on cohesion policy, of which Poland is the largest beneficiary. We shall assume then that this matter will be strongly disputed in order to maintain financial commitment of the UK even after it leaves the structures. The situation is complicated because when arrangements for the current period have been made certain numbers were set until year $2023^{14}$. That agreements have become a significant element of economic development strategy of Poland.

${ }^{13}$ It shall be added that in the part where art. 50 of TEU is about EU Council and European Council members (art. 50, para. 3, TEU) it refers only to taking decisions that refer only to the state concerned, and in this case it would be the UK. The above issue is not discussed there at all.

14 It refers to years 2014-2020, during which some projects will be performed even until 2023 - according to the $n+2, n+3$ principle. Projects started during budgetary period are allowed to be finished through next 2 , and in some cases during 3 years. It is aimed at reasonable planning of large projects (i.e. infrastructural), and shall help effective use of granted resources (see MIiR, 2015, p. 95, 206-220). 
Another important aspect of the negotiations will be the issue of legal status of workers and entrepreneurs form EU member states, who will work or do business on the territory of UK after the exit. It is estimated that there are now about 900 thousand Poles on the territory of the United Kingdom (ONS, 2016, table 2.6) ${ }^{15}$. It is important then to ask for future work and stay permission procedure, or for running a business (which actually might not be granted). Also - how protection of free competition will look like (in regard to discrimination based on the country of origin), which is strictly regulated in EU law.

Having that in mind it is hard to deny that Brexit, as a challenge for the EU, will seriously refer to Polish businesses. The negotiations will lead to a significant modification of the current legal order and that elements are now in the center of focus of Polish non-public entities. It is important that Polish arguments are heard and that simultaneously our representatives have strong social support. In that special case it is crucial to include private partners in creating the standpoint. On the one hand, our government will have good knowledge about actual needs and expectations of non-public actors and on the other, non-public entities must have good recognition of the negotiations and their complexity, including mutual relations that occur between certain policies under negotiation. It is even more important as some compromise may turn out to be necessary ${ }^{16}$.

The issue that during the last years has often occurred, and it cannot be regarded as a surprise, is the method how EU foreign policy is regulated. Although, in public debate it is hard to find such definition of the problem, but in the analysis of some detailed matters one shall agree that it what this is about. Here the key role, which is still a current problem, play refugees from domestic war territories in Syria or other countries affected by the so-called 'Islamic State'. The agreement with Turkey on establishment of refugee camps on their territory has for some time stopped wave of population coming to Europe. Still, it is hard to state that this issue is solved. The EU has been criticized for sluggishness in action towards refugees, but also for a lack of strong steps aimed at stopping reasons of such a situation. However, from the formal point of view,

${ }^{15}$ As it is shown by the British Office for National Statistics - ONS, 803 thousand (+/- 41 thousand) were born outside the UK and 108 thousand (+/- 15 thousand) already in the UK (ONS, 2016, table 2.6.).

${ }_{16}$ Definitely it might be really tempting not to include non-public entities into complexity of negotiations just in order to gain political support by blaming Brussels for possible concessions towards London. On the other hand, taking the opposite strategy and clear presentation of the situation to domestic non-public actors and close cooperation of central authorities with Brussels might, in fact, strengthen chances for success. 
according to EU foreign policy decision-making procedures, that would have to mean making unanimous decision of the 28 in regard to that hard issue ${ }^{17}$. This refers especially to such issues as providing humanitarian aid, agreement on joint standpoint and dynamic negotiations with fighting sides in Syria, as well as talks with its neighbors or states interested in the situation (such as Russia or the United States). If we consider diversity of affairs or attitudes of certain EU members towards the basic problem here, which is involvement in activity on the territory of the so-called 'Islamic State', but also of the Bashar Al-Assad regime, it seems that is actually impossible. However, that could be the reason why it is even more important to be clear towards non-public entities, so that existing standpoints on the whole issue of activity (or its lack) of the EU in that matter, are based on full knowledge of complexity of the issue ${ }^{18}$.

Another recent example, in which a similar scheme of expectations and difficulties is observed, is the still unsolved problem of aggression on Ukraine. It is mostly about sanctions towards Russia after annexation of Crimea and about its strengthening after Russian army has increased its activity on the territory of Ukraine, as well as about difficulties with introduction of the sanctions. In reaction to that conflict, EU member states presented highly divergent standpoints (see: Ćwiek-Karpowicz \& Secrieru, eds, 2015, p. 33-34). Another example could be external aspect of EU energy policy, where the lack of a single position towards suppliers, mostly (again) Russia, highly weakens the power of each member state. It especially refers to weaker states (see: tvn24, 2014).

17 One shall have in mind that all system changes made so far have left foreign policy outside supra-state level - in hands of national governments of member states. This is why decision procedures have been in accordance with inter-governmental model of international organization, meaning - the demand to take mostly all decisions unanimously and with the right to veto.

18 It shall be mentioned that in the Polish political system "the issue of refugees" is being linked to EU internal aspect of the issue and has caused special controversies (see: Sasnal, ed., 2015). It has been noticeable especially after proposal from the Commission to set a constant number of refugees, which each state should accept (see: CBOS 2016b; Info Uchodźcy, 2016). External aspect of the issue has been seen somehow as detached from the internal one, where in Poland it meant putting special attention to national identity (PAP, 3.06.2016). An interesting comment comes from Fundacja Batorego, of which experts claim that in Polish society national identity is defined in a rather closed way, which results from its ethnical and religious homogeneity. Besides that, another element supporting observable nationalistic moods is a much larger level of social conservatism of Poles in comparison to most of Europeans (Balcer, Gromadzki \&Smolar, 2016, p. 10-11). 
While searching for solutions and improvements for the EU it is hard not to ask whether states, or rather member-states societies, are ready to take decisions on the establishment of a common foreign policy? Such question is necessary because a broader perspective on dilemmas presented at this stage of the analysis shows that improvement of decision-making processes at the EU level (including abandoning the principle of unanimity) and boosting effectiveness, through quick achievement of common standpoint, within international arena activity, are inseparable. They are two sides of the same coin. By simplifying decision-making procedures EU's ability to efficiently react to external difficulties would be raised. Current situation shows how much - due to a gained level of integrity of political systems - steps of single member state not coordinated with EU activity on the international arena, might in the future cause negative consequences for other members ${ }^{19}$. One may say then that there circumstances for establishment of EU common foreign policy do exist, but we shall answer 'no' to the question stated before. It is still an area of state activity, which is too much associated with their classical independence. Creating a foreign policy based on rules similar as in economic policies on the internal market, would naturally have to mean limiting competences of member states in that matter and Polish society is not ready for that.

A factual discussion on this matter is necessary right now. It will enhance understanding complexity of the current situation as well as motives of taken decisions. Besides, during such a debate, it may turn out that new suggestions of solutions, are worked out, partially - referring to EU policy. An example is Polish proposal of common energy policy. Additionally, another valuable effect of such a debate would be the establishment of a coherent strategy for Poland towards external EU activity - supranational union policy. That indeed should be regarded as one of potentially crucial goals for Polish politics for the coming years. To do that a committed society is needed, ready to take part in some projects, not only as recipient, but also as some sort of an intellectual resource, that could bring added value to the decision-making process.

Another issue, which has to be noticed, is the issue of remarks of the Commission in regard to breaching rules of law in Poland (EC, 2016a). Of course one may say that despite Poland being mostly an interested party here, it is only an exchange of letters between the union and one of member states, without an attribute of a crucial case to the EU political system. Indeed, now the Commission

19 As an ex ample we may bring a statement, issued some time ago, presented by Angela Merkel, that Germany is ready to welcome all refugees, who will get to them. 
acts based on the procedure adopted in 2014 (EC, 2014), of which the main goal is to 'only' explain doubts on member state proceedings. The issues starts to have a much deeper scope if we take a closer look at the subject of the letters and possible consequences that might appear in the future.

The Commission especially considers that the Polish authorities do not respect and fully implement the judgments of the Constitutional Tribunal of 3 and 9 December 2015. That judgments refer to election of three members of the Constitutional Tribunal during previous term of the parliament and a lack of legal basis to elect another judges by the current parliament ${ }^{20}$. What is more, despite these judgments, the three judges nominated by the previous legislature have not taken up their function of judge in the Constitutional Tribunal and their oath has not yet been taken by the President of the Republic ${ }^{21}$. Conversely, the oath of the three judges nominated by the new legislature has been taken by the President of the Republic. Those are the main reasons the Commission is of the opinion that there is a situation of a systemic threat to the rule of law in Poland. The EC sees that as a situation where the Constitutional Tribunal is prevented from fully ensuring an effective constitutional review, which in turn

20 Ahead of the general elections for the Sejm of 25 October 2015, on 8 October the outgoing legislature nominated five persons to be 'appointed' as judges of the Constitutional Tribunal by the President of the Republic. Three judges would take seats vacated during the mandate of the outgoing legislature while two would take seats vacated during that of the incoming legislature which commenced on 12 November 2015. On 25 November 2015, the Sejm passed a motion annulling the five nominations by the previous legislature and on 2 December nominated five new judges. In its judgment of 3 December (TK Judgment, 2015a), the Constitutional Tribunal ruled inter alia that the previous legislature of the Sejm had been entitled to nominate three judges replacing the judges whose terms expired on 6 November 2015. At the same time, the Tribunal clarified that the Sejm had not been entitled to elect the two judges replacing those whose term expired in December. The judgment also specifically referred to the obligation for the President of the Republic to immediately take the oath from a judge elected by the Sejm. On 9 December (TK Judgment 2015b), the Constitutional Tribunal inter alia invalidated the legal basis for the nominations by the new legislature of the Sejm of the three judges for the vacancies opened up on 6 November 2015 for which the previous legislature had already lawfully nominated judges (EC, 2016b, pt 3-7).

${ }^{21}$ In addition, the situation is complicated by the fact that on 22 July 2016, the Sejm adopted a new Law on the Constitutional Tribunal. Article 90 of this Law states that "With effect from this Act's entry into force, the President of the Tribunal shall include on panels ruling on cases, and assign cases to, judges of the Tribunal who have taken the oath before the President of the Republic but, by the date of this Act's entry into force, had yet to take up their duties as judges" (See EC, 2016b, pt 11). 
adversely affects its integrity, stability and proper functioning, which is, according to the EC, one of the essential safeguards of the rule of law in Poland ${ }^{22}$. On that grounds the EC officially recommends in particular that the Polish authorities:

- implement fully the judgments of the Constitutional Tribunal of 3 and 9 December 2015 which require that the three judges that were nominated in October 2015 by the previous legislature take up their function of judge in the Constitutional Tribunal, and that the three judges nominated by the new legislature do not take up the post of those judges nor take action in issuing sentences without being validly elected;

- ensure that any reform of the Law on the Constitutional Tribunal respects the judgments of the Constitutional Tribunal, including the judgments of 3 and 9 December 2015, and takes the Opinion of the Venice Commission fully into account;

- take the opinion of the Venice Commission fully into account (EC, 2016b, pt 74).

In case of not following these recommendations the EC will take action according to art. 7 TEU. It might even lead to deprival of voice in the Council of the European Union (TEU, art. 7, para. 1 \& 3) ${ }^{23}$. Polish authorities stand on the position that no violations have taken place and that activity of the Commission does not have any legal basis in the treaties (Cedro \& Krzyżanowska - PAP, 2016; Biuro Rzecznika Prasowego MSZ, 2017).

The situation is complicated. On the one hand, taking the risk and remaining conflicted with the Commission, which might be harmful, demands a strong social mandate. On the other - such activity, at the union level, might strengthen national debate. Most of law experts are on a clear position that actually Polish central authorities did break state provisions, including the Polish constitution ${ }^{24}$.

22 What's more, the EC considers respect for the rule of law as a prerequisite for upholding all rights and obligations deriving from the Treaties and from international law, and for establishing mutual trust of citizens, businesses and national authorities in the legal systems of all other Member States. (EC, 2016b, pt 72-73). (For more on the Commission's reservations and its recommendations see KE, 2016c).

${ }^{23}$ Of course in order to punish Poland unanimity between member states will be necessary (TEU, art. 7, para. 2).

24 For example, Assembly of the Supreme Court, State Board of Solicitors, Supreme Bar Council, Ombudsman, numerous university faculties of law and recognized constitutional law professors, as well as large number of any kind of NGOs (Obserwator Konstytucyjny, 2016; PAP/IAR, 2015; tvn24, [MW/kk], 2016; Szuleka, Wolny \& Szwed 2016, p. 14-23). See also: Open letter to EU Commissioners, February, 16, 2017, signed by 
It may turn out that public participation of Polish non-public bodies is really necessary, but not in the context of support for its own state authorities in the conflict with the Commission, but to influence Polish public bodies to change their standpoint. In that case actions of the union institution might be an interesting example that stimulates or strengthens public participation.

No matter what the future is going to be, that issue might turn out to be very important for the whole Union. For the first time we may witness such advanced procedure that limits rights of a member state. Each next action of the Commission, but also of Polish authorities, will somehow set the track regarding interpretation of EU regulations in that matter. It could be significant also for the whole EU as it may coerce taking into account rethinking values which the Union is build on and how important it is to respect them when designing place of a state in the union's political system structure. Another concern is how far EU institutions could go if they come to a conclusion that these standards have been broken.

A general look at all presented cases brings us to a conclusion that participation of non-public entities in decision-making processes of state central organs, that refer to EU issues, has to be strengthened. As a consequence it is justified to ask about steps, which Polish interested parties should take to have a positive impact on the commented situation. Conclusions from the analysis and proposals of steps possible to be taken in order to upgrade the level of public participation.

\section{Conclusions}

At the start of an analysis of steps that could be taken by various parties of decision-making process, one shall start with an observation that public participation is mostly build upon local communities and public policy created at that level. However, it does not mean that bodies such as parliament and government cannot make their performance more efficient in order to enlarge participation.

more than 70 non-governmental organizations that act within protection of rules of law from Poland and other countries, including Human Rights Watch, Helsinki Foundation for Human Rights or Amnesty International. According to the letter, signatories call the Commission to 'stop Poland from turning away from common founding values of the $\mathrm{EU}$ and to take next steps determined in art. 7 of the TEU' (Amnesty International, et al., 2017). 
First of all, one shall refer to examples from the EU. To be more specific - that refers to approach of the Commission, which lacks numerous resources of expert knowledge, and which still deals with the problem of legitimization of its own public decisions. Due to that, it has to develop certain mechanisms (partially already present in Polish legal system) of gathering information and opinions from interested parties, while at the same time build support for adopted solutions that are based on that mechanism (See: Broscheid \& Coen, 2003, p. 170). And so the EC prepares the so-called white and green papers, and in order to make contacts easier it often organizes various public hearings and meetings of members of certain general managements with independent experts or representatives of interest groups ${ }^{25}$. What is important, internet opinion-sharing platforms begin to play a greater role. That makes it easier for the Commission to ask for information on a topic, as well as it creates an opportunity to speak out for as many interested parties as possible. One of the most popular internet opinion-sharing portals, that operates according to standards of the Commission, is 'Your voice in Europe' (EC, 2016c).

Within Polish political system one shall demand more intense use of white and green papers, as well as establishment of a permanent platform for consultations of acts that are being prepared. Similar to general managements of the Commission also ministries could publish the most important legal acts drafts, in order to put them under public discussion ${ }^{26}$. Such an approach would increase trust of citizens towards public authorities and could strengthen mutual relations. Better cooperation may also result from any action aimed at improvement of public administration performance, especially in regard to its effectiveness ${ }^{27}$

25 In July, 23rd, 2011, transparency register shared by the Commission and by the EP has been launched, which will be used to register and control organization and selfemployed people engaged in work on EU policy implementation (Agreement between EP and EC 2011).

${ }^{26}$ Draft code of public consultations, created an experts' group under the auspices of the Ministry of Administration and Digitalization, may turn out to be helpful (See: Steiner, et al. 2012, p. 3).

27 Bureaucrats often fail to use solutions that would guarantee institutional knowhow, for example: databases with letter templates or finished projects. Team work is exceptional, as well as cooperation with external experts, who support learning of employees and develop their potential. Often the so-called 'loss of knowledge' takes place, which results from high rotation of employees, which causes a situation, when it is hard to reestablish the previous decision-making process (See: Zybała 2014, after KPRM 2011, p. 25-27). 
and openness for cooperation with non-public entities, according to new public governance principles (Zybała, 2013, p. 9-12).

Some changes, with relatively small effort and resources, could be introduced also by the parliament. Of course one cannot 'decree' greater participation, but definitely it may take formal steps that will make it stronger ${ }^{28}$. We may point to now to civic legislative initiative, within which right to propose a draft belongs to a group of at least 100 thousand citizens with electoral rights ${ }^{29}$. In that case parliamentary activity could concentrate on liquidation of the most often mentioned barriers of practical application of that method of participation. It is about extension of time that citizens have to collect enough signatures, but also - in regard to matters when the proposal has accepted for further proceedings - prolongation of suspension time of the principle of discontinuation ${ }^{30}$. Apart from that, especially political parties that have parliamentary representation should put more attention to the quality of debates, as well as put more effort

${ }^{28}$ With satisfaction one shall regard more attention that has been put to development of public participation by Polish legislator, expressed in current strategic documents, meaning - State Development Strategy 2020 (Chamber of Ministers, 2012) and related to it - Social Capital Development Strategy 2020 (Chamber of Ministers, 2013a) and Efficient State Strategy 2020 (Chamber of Ministers 2013b).

${ }^{29}$ That right is found in art. 118 of Polish Constitution and is regulated in detail in the Act on Execution of Citizen Legislative Initiative (Act No. 688/1999). In order to propose a civic draft a committee has to be formed, which shall be registered after a declaration is forwarded to the Marshal of the Senate. Next it has three months to collect enough signatures that enables submission of the draft for further parliamentary proceedings.

${ }^{30}$ Number of such initiatives is significant. Since 1999 till the end of 2013 about 120 notifications on establishment of civic committee have been submitted to the Speaker of the Senate, which shall be regarded as a broad use of such a path of participation. Still, the procedure and its evaluation get different opinions. First of all, the Speaker does not have to (and indeed not always does) allow registration of a committee. Of course, at this stage the greatest problem seems to be too short a time to collect all necessary signatures. During the analyzed period as many as 51 committees did not make it to submit the draft on time along with a proper number of signatures. In general, from 116 committees only 42 managed to successfully proceed with their draft to parliamentary proceedings stage. Next, the largest obstacle for committees, that went through the first stage, turned out to be the discontinuation principle. In practice, drafts not proceeded during parliamentary term, within which they have been submitted or during the next one, are finally lost. It is a common practice, that after the first reading a draft is sent to a commission, and there it takes longer that it should. During the mentioned period only 12 civic drafts have been adopted, and not all of them have got their final shape the same as submitted (See: Website - Obywatele decydują, 2015). 
to present more substantive content, not aimed at generating political tensions and negative emotions. In a longer time period such an approach may bring more benefits than a level low discussions which cause aversion to politics and authorities.

On the other hand, one shall not demand extension of participation only to public entities. Notice that in some circumstances the initiative shall be in the hands of such actors as NGOs, think tanks, individual citizens and the media. Their activity does not always have to be limited to just putting forward legislative drafts, proposals of referendums, encouraging people to take part in consultations or organization of protests aimed at pressure on public authorities. Sometimes this is enough, but it is also extremely valuable to reach as many people as possible with an honest explanation of the situation ${ }^{31}$.

The situation related to challenges awaiting Poland in regard to its membership in the EU shows well how important is gathering information and verifying data by non-public entities on their own as well as the will to take steps towards expressing your own opinion. It turns out that matters related to the EU system might well become an object of political game, in which non-public entities would be only recipients of narration of central public power organs in regard to

31 Here, as the most significant example, may serve the case of entrance of Poland into the euro zone. After analysis of the situation throughout last years one may say that within Polish approach towards that issue significant dissonance between opinions of intuitions with public finances expert knowledge and majority of the society. Arguments and remarks presented by the Polish National Bank are clearly on the fact that entering the euro zone would demand large preparations. But still the bank is of the opinion that it is necessary and it is an opportunity for development. The situation is different if we compare it with results of surveys among the society (Compare, Narodowy Bank Polski, 2014, p. 122-125, 147-148; CBOS 2014c, p. 5, 7-8, 10). Of course, in that situation it would seem necessary to organize a large informational campaign, led also by public bodies, which would inform a wide spectrum of non-public entities about detailed results of analyses and simulations. Only that would make it possible to explain what are the sacrifices and long-term benefits. Especially in the face of perpetuating division to two-speeds Europe, where one of major demarcation lines is membership in the euro zone, it seems legitimate to say that in Poland the issue of adopting euro is more perceived as a matter of emotions and political preferences than economic knowledge. However, that is why, if we take into account political situation, including strong support to euro-skeptic forces, there will be not enough motivation on the side of political actors to conduct such an action. That is why it may turn out that in the coming years the burden of such informational campaign, resulting greater knowledge and better preparations to substantial decision, will be in the hands of independent non-public entities, such as NGOs or think-tanks. 
decisions these bodies have made on their own or are going to make. Distant and blurred system of the EU (if it will be like that in the future) will each time serve as a good candidate to be blamed for all worsening of situation of non-public entities. Remarks presented above, about bottom-up stimulating participation may be right also in the perspective of development of EU (the Commission)-Poland situation in regard to breaching rules of law. Standpoint of Polish authorities is intransigent, and it is hard to deny that they are a direct party of the conflict. The ability to work out a standpoint on your own may turn to be necessary for non-public entities as recipients of outcomes of such a conflict, in order to be able to stand on one of the sides, and to be able to make an impact on the one who is breaching the treaties.

The case of Brexit could also serve as a good confirmation of the logics of putting more emphasis on broadening knowledge among non-public entities. It seems that in that case improper understanding of EU decision-making mechanisms and of dependencies among various EU politicians had a significant impact. After a detailed investigation of the referendum campaign it shall be added that also politicians have their share here ${ }^{32}$. It is significant because of challenges presented here that still await the EU. It will be necessary to seek and introduce difficult and controversial solutions. Their implementation will definitely shed light on how the EU will be perceived, as well as on Polish membership. Although today the membership has strong social support - 81 percent in February 2016 (CBOS, 2016a, p. 2) - we cannot still forget that current attitudes, reluctant towards the EU in many dimensions are strong, and in the future they may move even closer to end the contact, among others because probable drop of EU financing, as the institution is perceived mostly as a money resource. A lack of understanding of the ongoing processes, necessary to reform the EU, might only intensify such attitudes. 'The question how much Poles still identify themselves with the European choice, regarded as a cultural and axiological choice, is not an abstract question, but has a great meaning for position of Poland and Europe (Balcer, Gromadzki \& Smolar, 2016, p. 18-19)'.

The presented analysis of selected challenges that are ahead of the EU, of course does not include all possible situations that may occur in the near future and that would demand reforms of EU public policies. Such demand is highly

32 See: Nigle Farage admitting in public that one of his key arguments in favor of the exit that he has presented during the campaign - was not true. It was about transferring 350 million $£$ to British national health care system, which GB should save each week after the exit (Gazeta.pl, 2016). 
probable. Still, already presented problems make us confident that for a smooth development of Poland and efficient decision making, in regard to EU public policies, high-quality public participation is very useful.

A high level of participation is hard to achieve. Poles do not have a proper habit of participation, and they distance themselves from state institutional structures, or from political parties, which play key role in representative democracy. Poles declare a limited trust towards them. Only 40 percent trust public administration organs. Even less trust the legislative power - 34 percent - and the executive - 33 percent. The smallest number trusts political parties 17 percent (CBOS 2014b, p. 3).

Such a situation makes it difficult to gain social support towards decisions taken in regard to such vivid decisions as relations between the EU and member states. Besides, it has a bad impact on the will of non-public entities to cooperate. One may then say that both - parliament and government, except for informational activity ${ }^{33}$, should put more effort to real inclusion of non-public entities in the decision-making processes. It will help enhance quality, broaden knowledge among Poles, but also strengthen social trust towards the institution of the state. It will all turn into better performance of Poland within EU public decision making. On the other hand - at the same time - non-public entities shall show some own initiative. Challenges ahead of Poland are serious and therefore the decision of not taking part in the process of solving them might after all turn out to be a wrong attitude.

\section{REFERENCES}

Act (1240/2009) of 27.08.2009 on public finances [ustawa o finansach publicznych], Dz.U. RP of 2009 No 157, pos. 1240 with further amendments.

Act (177/2004) of 29.01.2004 public procurement law [ustawa prawo zamówień publicznych], Dz.U. RP of 2004 No 19 pos. 177 with further amendments.

Act (688/1999) of 24.06 .1999 on the implementation of the legislative initiative by the citizens [ustawa o wykonywaniu inicjatywy ustawodawczej przez obywateli], Dz.U. RP of 1999, No 62, pos. 688, with further amendments.

Amnesty International, FIDH (International Federation for Human Rights), Human Rights Watch, Open Society European Policy Institute \& Reporters without Borders, (2017), An opened letter of 16.02.2017 to EU Commissioners, Brussels.

33 In regard to presentation of substantiation of certain single decisions, but also to EU public policies or the very structure and decision-making mechanisms. 
Balcer A., Gromadzi G. \& Smolar E. [Raport Fundacji Batorego] (2016), Polacy wobec UE: Koniec konsensusu, Warszawa.

Barcz J. (2016), Brexit - w sprawie interpretacji postanowień art. 50 Traktatu o Unii Europejskiej, „Europejki Przegląd Sejmowy”, 12, pp. 4-14.

Biernat S. (1994), Prywatyzacja zadań publicznych. Problematyka prawna, Warszawa-Kraków.

Biuro Prasowe Rzecznika MSZ (2017), Oświadczenie MSZ z 20.02.2017 dotyczące odpowiedzi strony polskiej na uzupełniające Zalecenie Komisji Europejskiej z dnia 21.12.2016, retrived from http://msz.gov.pl/pl/aktualnosci/wiadomosci/oswiadczenie_msz_dotyczace_odpowiedzi_strony_polskiej_na_uzupelniajace_zalecenie_komisji_europejskiej_z_dnia_21_grudnia_2016_roku?channel=www.

Broscheid A., Coen D. (2003), Insider and Outsider Lobbying of the European Commission. An Informational Model of Forum Politics, „European Union Politics”, 2(4), pp. $165-191$.

CBOS (2014a), Komunikat z badań 42/2014, Opinie o demokracji, Warszawa.

CBOS (2014b), Komunikat z badań 68/2014, Stosunek do instytucji państwa oraz partii politycznych po 25 latach, Warszawa.

CBOS (2014c), Komunikat z badań 151/2014, Narastanie obaw związanych z wprowadzeniem euro, Warszawa.

CBOS (2016a), Komunikat z badań 31/2016, Polska w Unii Europejskiej, Warszawa.

CBOS (2016b), Komunikat z badań 79/2016, Stosunek do przyjmowania uchodźców po ogłoszeniu nowej propozycji Komisji Europejskiej dotyczącej reformy polityki azylowej, Warszawa.

Cedro M. \& Krzyżanowska E. - PAP (2016), Informacja z dnia 4.11.2016, Rząd w odpowiedzi dla KE: nie dostrzegamy prawnych możliwości realizacji zaleceń, retrived from http://wiadomosci.wp.pl/rzad-w-odpowiedzi-dla-ke-nie-dostrzegamy-prawnychmozliwosci-realizacji-zalecen-6054918213603969a.

Ćwiek-Karpowicz J. \& Secrieru S. (red.) (2015), Sankcje i Rosja, Warszawa.

Długosz D., Wygnański J. J. \& Tański M. (wstęp i redakcja) (2005), Obywatele współdecydują. Przewodnik po partycypacji społecznej, Warszawa.

Elliott J., Heesterbeek S., Lukensmeyer C. J. \& Slocum N. (2003), Participatory methods toolkit. A practicioner's manual http://archive.unu.edu/hq/library/Collection/ PDF_files/CRIS/PMT.pdf.

European Commission (2016a), Commission Opinion of 1.6.2016 regarding the Rule of Law in Poland, Brussels, C(2016) 3500 final.

European Commission (2016b), Commission Recommendation of 27.7.2016 regarding the rule of law in Poland, Brussels, C(2016) 5703 final.

Gazeta.pl (2016), Największe oszustwo Brexitu? Kilka godzin po referendum okazuje się, że kluczowa obietnica nie zostanie zrealizowana [information of 24.06.2016], retrived from http://wiadomosci.gazeta.pl/wiadomosci/10,150682,20297475,najwieksze-oszustwo-brexitu-kilka-godzin-po-referendum-okazuje.html. 
Gramberger M. (2001), Citizens as partners. OECD handbook on information, consultation and public participation in policy making, Paris.

Info Uchodźcy (2016), Stosunek Polaków do uchodźców, retrived from http://uchodzcy. info/infos/stosunek-polakow-do-uchodzcow/.

Judgement of the Constitutional Tribunal (2015a) of 3.12.2015 in case K-34/15 on compliance of the selected provision of the Act of 25 November 2015 on Constitutional Tribunal with Constitution, retrived from http://isap.sejm.gov.pl/Download;jsessio nid=E52B3A7A9BA632F07C8641B37D1A8DE0?id=WDU20150002147\&type=1.

Judgement of the Constitutional Tribunal (2015b) of 9.12.2015 in case K-35/15 on compliance of the Act of 19 November 2015 amending the Act on Constitutional Tribunal with Constitution, retrived from http://isap.sejm.gov.pl/Download;jsessionid=E52B 3A7A9BA632F07C8641B37D1A8DE0?id=WDU20150002147\&type $=1$.

Kancelaria Prezesa Rady Ministrów (2011), Diagnoza zarząadzania zasobami ludzkimi w służbie cywilnej. Załącznik Nr 2 do strategii zarządzania zasobami ludzkimi w służbie cywilnej (04.05.2011), retrived from https://dsc.kprm.gov.pl/sites/default/ files/zal_2_diagnoza_2013.09.20.pdf.

Kaźmierczak T. (2011), Partycypacja publiczna: pojęcie, ramy teoretyczne. In A. Olech (red.), Partycypacja publiczna. O uczestnictwie obywateli w życiu wspólnoty lokalnej, Warszawa, pp. 100-111.

Komisja Europejska (2014), Komunikat Prasowy KE z 11.03.2014: Ochrona państwa prawnego w Unii Europejskiej - Komisja Europejska przedstawia nowe ramy prawne, Strasburg.

Komisja Europejska (2016c), Zalecenia Komisji z 21.12.2016 w sprawie praworządności w Polsce stanowiące uzupełnienie Zaleceń Komisji (EU) 2016/1374, C(2016) 8950 final.

Komisja Europejska (2016c), strona Komisji, Zakładka: Udział obywateli w kształtowaniu prawa, Retrived from http://ec.europa.eu/yourvoice/index_pl.htm.

Krzyżanowska Ł., Faciejew Ł. (2009), Partycypacja obywatelska w Polsce. Menu raportu dla Fundacji Batorego, Warszawa.

Ministerstwo Infrastruktury i Rozwoju, Stałe Przedstawicielstwo RP przy UE (2015), Podręcznik komentarz do rozporządzeń unijnych dla polityki spójności na lata 2014-2020, Warszawa.

Narodowy Bank Polski (2014), Ekonomiczne wyzwania integracji Polski ze strefą euro, Warszawa.

Obserwator Konstytucyjny (2016), Sędziowie domagają się respektowania wyroków Trybunału Konstytucyjnego, (4.04.2016), retrived from http://www.obserwatorkonstytucyjny.pl/trybunal/sedziowie-domagaja-sie-respektowania-wyrokow-trybunalukonstytucyjnego/.

Obywatele Decydują, Zakładka: Stan Obecny, (2015), retrived from https://obywateledecyduja.pl/merytorycznie/stan-obecny. 
Office for National Statistic - ONS (2016), Population of the United Kingdom by Country of Birth and Nationality in 2015, (25.08.2016), retrived from https://www.ons. gov.uk/peoplepopulationandcommunity/populationandmigration/internationalmigration/datasets/populationoftheunitedkingdombycountryofbirthandnationalit.

Olech A. \& Kaźmierczak T. (2011), Modele partycypacji publicznej. In A. Olech (red.), Partycypacja publiczna. O uczestnictwie obywateli w życiu wspólnoty lokalnej, Warszawa, pp. 83-99.

PAP (2016), Eksperci: Polska nie ma polityki integracyjnej, problemem traktowanie uchodźców jako zagrożenia Gazeta Prawna, (3.06.2016), retrived from http://www.gazetaprawna. pl/artykuly/949131,eksperci-polska-nie-ma-polityki-integracyjnej-problememtraktowanie-uchodzcow-jako-zagrozenia.html.

PAP/IAR (2015), Spór o Trybunał Konstytucyjny. Jest stanowisko Naczelnej Rady Adwokackiej, (8.12.2015), retrived from http://www.polskieradio.pl/5/3/Artykul/1555085,Spor-o-Trybunal-Konstytucyjny-Jest-stanowisko-Naczelnej-Rady-Adwokackiej.

Porozumienie między Parlamentem Europejskim a Komisją Europejską (2011) z dnia 23.06.2011 w sprawie utworzenia „Rejestru służącego przejrzystości” dotyczącego organizacji i samozatrudnionych osób, zaangażowanych w opracowanie i realizację polityki Unii Europejskiej, Dz.U. UE L 191 of 2011.

Rada Ministrów (2012), Strategia Rozwoju Kraju 2020 - opublikowana jako Załącznik nr 1 do uchwały rady ministrów nr $157 \mathrm{z}$ dnia 25.09.2012, M.P. of 2012, pos. 882.

Rada Ministrów (2013a), Strategia Rozwoju Kapitału Społecznego 2020 - opublikowana jako załącznik do uchwały rady ministrów z dnia 18.06.2013, M.P. of 2013 pos. 378.

Rada Ministrów (2013b), Strategia Sprawne Państwo 2020 - opublikowana jako załącznik do uchwały rady ministrów z dnia 12.02.2013, M.P. of 2013, pos. 136.

Rada Ministrów (2014), Wieloletni plan finansowy państwa na lata 2014-2017, cz. I Plan konwergencji - Aktualizacja 2014, Kwiecień 2014, retrived from http://www.mf.gov. pl/documents/764034/1002171/WPFP+na+lata+2014-2017.pdf

Reid A. S. (2016), Brexit Begins: an overview of the legal issues (28 July 2016), retrived from http://eulawanalysis.blogspot.com/2016/07/brexit-begins-overview-of-legalissues.html.

Sasnal P. (red.) (2015), Niekontrolowane Migracje do Unii Europejskiej, Warszawa.

Steiner Małgorzata et al., [Raport sporządzony dla Ministerstwa Administracji i Cyfryzacji] (2012), Konsultacje społeczne - jak sprawić by były lepsze? Propozycja Kodeksu Konsultacji i ścieżka wdrożenia, czerwiec 2012, retrived from https://mac. gov.pl/files/konsultacje-spoleczne.pdf.

Szuleka M., Wolny M. \& Szwed M. [Raport Helsińskiej Fundacji Praw Człowieka], (2016), Kryzys konstytucyjny w Polsce 2015-2016, Warszawa.

TEU (2002): Treaty on European Union, consolidated version of the 2002, OJ EC C 325 of 2002.

TFEU (2012): Treaty on the Functioning European Union, consolidated version of the 2012, OJ EU C 326 of 2002. 
Tvn24 [MW/kk], Spór wokół Trybunału. Jakie konsekwencje odczuje przeciętny obywatel?, (07.04.2016), retrived from http://www.tvn24.pl/wiadomosci-z-kraju,3/sporwokol-trybunalu-jakie-konsekwencje-odczuje-przecietny-obywatel,633697.html.

Tvn24 (2014), Unia energetyczna, czyli co? (2.05.2014), retrived from http://tvn24bis.pl/ wideo/unia-energetyczna-czyli-co,1279782.html

Zybała A. (2014), Wokół zagadnienia partycypacji w Polsce, retrived from http://www. decydujmyrazem.pl/o_projekcie/wiadomosci/wokol_zagadnienia_partycypacji_w_polsce.html.

Zybała A. (2013), Wyzwania w sektorze publicznym, „Animacja Życia Publicznego Zeszyty Centrum Badań Społeczności i Polityk Lokalnych”, 1(8), pp. 9-12. 